ISSN 1045-6333

\title{
HARVARD
}

John M. Olin Center for Law, Economics, and Business

\section{THE TROUBLE WITH STAGGERED BOARDS: A REPLY TO GEORGESON'S JOHN WILCOX}

\author{
Lucian Arye Bebchuk \\ John C. Coates IV \\ Guhan Subramanian
}

Discussion Paper No. 410

$02 / 2003$

As published in

Corporate Governance Advisor, Vol. 11, No. 2, pp. 17-19 (2003)

The Center for Law, Economics, and Business is supported by a grant from the John M. Olin Foundation.

This paper can be downloaded without charge from:

The Social Science Research Network Electronic Paper Collection:

http://papers.ssrn.com/abstract_id=384980 


\title{
The Trouble With Staggered Boards: A Reply To Georgeson's John Wilcox
}

\author{
Lucian Arye Bebchuk, ${ }^{*}$ John C. Coates IV** \\ and Guhan Subramanian***
}

\begin{abstract}
$\underline{\text { Abstract }}$
In recent work, we presented evidence indicating that staggered boards have adverse effects on target shareholders. John Wilcox, the Vice-Chair of Georgeson recently published a critique of our work, urging shareholders to support staggered boards. In this paper we respond to Wilcox's critique and explain why it does not weaken any way our analysis of staggered boards.

The study criticized by Wilcox, "The Powerful Antitakeover Force of Staggered Boards: Theory, Evidence, and Policy, 54 Stanford Law Review 887951 (2002), is available at http://papers.ssrn.com/abstract=304388. In a separate reply, "The Powerful Antitakeover Force of Staggered Boards: Further Findings and a Reply to Symposium Participants," 55 Stan. L. Rev. 885-917 (2002), which is available at http:// papers.ssrn.com/abstract $=360840$, we respond to several other responses to our original study and present additional evidence that confirms its conclusions.

\section{JEL Classification: G30, G34, K22}

Key words: Takeover, mergers and acquisitions, tender offers, takeover bids, defensive tactics, staggered boards, poison pills, premia, independent directors.

Copyright 2003 Lucian Bebchuk, John Coates, and Guhan Subramanian.

\footnotetext{
* William J. Friedman and Alicia Townsend Friedman Professor of Law, Economics, and Finance, Harvard Law School; Research Associate, National Bureau of Economic Research and Center for Economic Policy Research.

** Professor of Law, Harvard Law School.

*** Joseph Flom Assistant Professor of Law and Business, Harvard Law School.
} 
Last spring we published a study of the costs that staggered boards impose on target shareholders. ${ }^{1}$ In a recent issue of the Corporate Governance Advisor, John Wilcox offered a critique of our study, ${ }^{2}$ urging shareholders not to support resolutions opposing staggered boards. We welcome his attempt to challenge our findings. As Vice-Chair of Georgeson \& Company, a major proxy solicitation firm active in helping incumbents oppose such resolutions as well as hostile bids more generally - Wilcox is as well positioned as anyone to offer a defense of staggered boards. His inability to undermine any element of our analysis is thus all the more telling. It should leave shareholders more dubious than ever about the value of staggered boards.

Our study focused on how an "effective" staggered board (ESB) - that is, a staggered board that cannot be dismantled or "packed" by a hostile bidder - affects the outcome of a hostile bid. We developed a theoretical account of how the combination of a staggered board and a poison pill can greatly impede hostile bids, and we tested our theory using a new data set of all hostile bids from 1996 to 2000.

1 Lucian Arye Bebchuk, John C. Coates IV \& Guhan Subramanian, "The Powerful Antitakeover Force of Staggered Boards: Theory, Evidence, and Policy," 54 Stan. L. Rev. 887 (2002).

2 John C. Wilcox, "Two Cheers for Staggered Boards," Corporate Governance Advisor (Nov/Dec. 2002). 
Our empirical analysis provided three main findings, none of which are challenged by Wilcox. First, an ESB nearly doubles the odds a target will remain independent, from $34 \%$ to $61 \%$. Second, when targets remain independent, their shareholders are, on average, significantly worse off compared with the shareholders of targets that either accept a bid or sell to a white knight. Third, ESBs did not provide higher premia in cases where targets were acquired. Putting these three findings together, we estimated that ESB's resulted in losses on the order of eight to ten percent for shareholders of hostile bid targets.

Based on these findings, we proposed that, at least absent explicit shareholder authorization, when incumbents protected by an ESB lose one election over an outstanding bid, courts should be reluctant to permit them to further block the bid by maintaining a poison pill. Our approach would be consistent with the fundamental principles on which takeover case law was built: to provide directors with substantial discretion to adopt and maintain pills, but to provide some safeguard on potential abuse by providing a viable "ballot box" safety valve.

Wilcox states that our study is "narrow in its methodology and oldfashioned in its reasoning." To support this, he makes several specific claims. First, he claims we look at shareholder premia as the primary measure of shareholder value. This claim, however, is incorrect. In assessing ESBs, we 
take into account both the premia that shareholders get in a takeover or sale to white knight and the value that their shares have in the event that the target remains independent. If target managers improve corporate value up to 30 months after a bid, that value is included in our study.

Wilcox also argues that we ignore the effect of staggered boards on negotiated acquisitions and claims that staggered boards provide benefits to target shareholders in such transactions. Other critics of our work have also relied on the potential benefit that staggered boards might have in negotiated deals. This alleged benefit has been stressed by Marin Lipton in a recent exchange with one of $\mathrm{us}^{3}{ }^{3}$ and has been hailed by Lipton's partner Mark Gordon in a symposium on our study that the Stanford Law Review published in its December issue. ${ }^{4}$ Surprisingly, even though Georgeson would seem to be well positioned to study empirically whether such a benefit exists, it has never attempted to do so. Wilcox, like other supporters of staggered boards, merely asserts the possibility of such a benefit.

In any event, in our reply to Gordon and others in the recent Stanford Law Review symposium, we provide some preliminary evidence on this point

3 Martin Lipton, “Pills, Polls and Professors Redux," 69 U. Chi. L. Rev. 1037 (2002).

4 Mark Gordon, “Takeover Defenses Work. Is That Such a Bad Thing?," 55 Stan. L. Rev. 819 (2002). 
based on a study of deals from 2000 to $2002 .{ }^{5}$ In this extension of our original article, we find no evidence to support Wilcox's claim that a staggered board benefits shareholders in negotiated transactions. In fact, although the results we report are preliminary - in that they are based on a relatively small sample (73 deals) - we find no difference in the premia received by shareholders of ESB and non-ESB targets in these negotiated transactions. ${ }^{6}$ While we hope that others will further investigate the subject, the evidence developed to date does not enable Wilcox, corporate lawyers, or others to advise boards to adopt (or maintain) staggered boards on the basis of this alleged benefit.

Additional evidence relevant to whether ESBs provide shareholder benefits in friendly deals is contained in two recent studies, one by Professors Hartzell, Ofek, and Yermack at the NYU Stern School of Business, and one by Professor Wulf at Wharton. ${ }^{7}$ These studies find that target managers accept lower premia in negotiated deals when managers receive favorable personal treatment, such as a position with the combined company. Thus, these

5 "The Powerful Antitakeover Force of Staggered Boards: Further Findings and a Reply to Symposium Participants," Stanford Law Review, December 2002.

6 To be precise, we find no statistically significant differences, and in fact, sample medians are lower for ESB targets, contrary to what the higher premia hypothesis would predict. Id.

7 See Jay Hartzell, Eli Ofek \& David Yermack, "What is in It for Me?: Personal Benefits Obtained by CEOs Whose Firms Are Acquired" (March 2000) (http:// papers.ssrn.com/sol3/papers.cfm?abstract_id=236094); Julie Wulf, Do CEOs in Mergers Trade Power for Premium? Evidence from “Mergers of Equals" (June 2002) (http:/ / knowledge.wharton.upenn.edu/show_paper.cfm?ID=1009). 
studies suggest that shareholders should be skeptical about whether managers' veto power operates in negotiated deals to the benefit of target shareholders.

Wilcox also criticizes our study for examining the impact of hostile bid outcomes on target shareholders but not on acquirers' shareholders. We agree that the impact on hostile bidders is an interesting subject, but we do not see how this issue can provide support for Wilcox's position. Wilcox is trying to convince shareholders voting on staggered board resolutions that a staggered board would benefit them. For this purpose, the question is how a staggered board would affect shareholders in the event that their company becomes a target; when the company is the acquirer, whether or not it has a staggered board is irrelevant. Interestingly, when Wilcox's own Georgeson put forward studies in the late 1980s concluding that poison pills were desirable, these studies examined only the impact of pills on target shareholders. ${ }^{8}$

Wilcox also argues that we ignore the question of whether hostile bids are coercive and that "[our] study wrongly assumes that a takeover premium guarantees victory in a proxy contest." In fact, our policy proposal is

8 Georgeson \& Co. Inc., Poison Pill Impact Study (Mar. 31, 1988); Georgeson \& Co. Inc., Poison Pill Impact Study II (Oct. 31, 1988). One of us has pointed out in prior scholarship that the design of such studies makes it impossible for them to be used fairly to support the idea that poison pills produce higher bid premia, as is often claimed. John C. Coates IV, "Takeover Defenses in the Shadow of the Pill: A Critique of the Scientific Evidence," 79 Tex. L. Rev. 271, 286-91 (2000). 
deliberately crafted to require bids to be non-coercive by effectively requiring them to be submitted to a shareholder vote before bidders are permitted to proceed with their bids. Furthermore, we explicitly indicate that a proxy contest over an offer can go either way, depending on whether shareholders find an acquisition at the offered price to be in their collective interest.

Wilcox seems to believe that we are advocating the deregulation of hostile bids, but in fact we are advocates of carefully regulating hostile bids: we suggest court intervention not against pills generally - which we believe serve the useful purpose of preventing a hostile takeover that does not win shareholder support in a vote - but only against incumbents maintaining pills to block bids after incumbents lose an election fought over the bid. The reason we would give weight to shareholder votes is not that they would necessarily go in favor of bidders, but because they would express shareholders' undistorted judgment on whether the acquisition would be in their interest.

In addition to questioning our analysis of the effects that staggered boards have on acquisition offers, Wilcox also speculates that staggered boards provide benefits outside of the acquisition context by enhancing director independence and providing for institutional stability. These benefits may exist, but a company can achieve them by simply adopting a policy or bylaw staggering board terms, rather than putting a staggered board into a charter amendment. The reason staggered boards are commonly 
put into the charter is not to commit the company to stability and board independence, but rather to prevent shareholders from being able to remove the board as a whole in a control contest.

Wilcox stresses in his piece that "[t]he lessons of Enron should cause shareholder activists to reconsider their opposition to staggered boards." He argues that the "market for corporate control cannot solve Enron-type problems" and that "good governance requires more than successful takeovers." We agree that improving the outcome of takeover contests would not cure all corporate governance problems. However, while we should not ignore other corporate governance problems and reforms, there is little reason not to improve the outcome of takeover contests as our approach seeks to do.

Wilcox concludes his piece by calling for those opposing and supporting staggered boards to agree that their appropriateness is "a matter of policy more than of economics" because "there is no economic evidence that companies with staggered boards fail to perform as well as companies with unitary boards." In fact, however, our study provides solid economic evidence, which Wilcox in no way undermines, that in the face of a hostile takeover bid companies with a staggered boards perform significantly less 
well than companies with a unitary board. ${ }^{9}$ This evidence points in the same direction as the traditions of Delaware corporate law - that courts should not permit hostile bids to be resisted unreasonably by directors, who inevitably face a type of conflict of interest when a hostile bid is made for their company. When shareholders vote, they should take into account that the evidence to date is clear: limiting the power of incumbents to block offers after losing a shareholder vote generally operates to the benefit of shareholders.

9 Our findings are consistent with another recent study that generally finds that companies with a large number of takeover defenses (including staggered boards) produce lower long-term shareholder returns than companies with few defenses. Paul A. Gompers, Andrew Metrick, and Joy L. Ishii, "Corporate Governance and Equity Prices," The Quarterly Journal of Economics 118(1), February 2003, forthcoming. 